\title{
The Effect of Leadership on the Work Motivation of Higher Education Administration Employees (Study at Manado State University)
}

\author{
Ficke H. Rawung ${ }^{1}$ \\ ${ }^{1}$ (Postgraduate/ Manado State University, Manado, Indonesia)
}

\begin{abstract}
This research is based on phenomenon of a work motivation of higher education administration employee in Manado State University. It's interesting to study the effect of leadership on the work motivation of higher education administration employee. These researches was conducted in Manado State University in Tondano City. This research uses quantitative method applying a survey approach. Respondents are education administration employees in Manado State University with 55 respondents. This research result the hypothesis, can be said according to the hypotesis leadership had a significant effect on work motivation. It can been seen in $\alpha$ below 0,05 or below $5 \%$. That indicate that hypotesis one accepted or relationship between leadership and work motivation is significant in this research. Leadership affectcs employee work motivation. That is, leadership to work motivation in higher education employee especially in Manado State University Tondano, North Sulawesi Indonesia. Leadership is useful to motivate employee work in the organization especially in higher education or university organization.
\end{abstract}

Keywords: Leadership, Work Motivation, Employee, Higher Education Administration

\section{INTRODUCTION}

Development of technology and information that occurs very quickly requires individuals who have the creativity and high productivity. In this case, technological developments and knowledge requires individuals who are able to adapt to the change. Therefore most organizations play an important role in preparing qualified human resources are educational institutions, like universities should be able to provide a quality education process and are able to create quality human resources as well. It requires not only the lecturers, researchers, but also the operational part of the university (Cortese, 2013), among others, human resources. The existence of human resource support through the work, talent, creativity, encouragement, and a real role. Without the human element in the higher education or university, the university may not be able to move and headed desired.

Work motivation is an populer topic in work and organizational science. It is broadly defined as 'a set of energetic forces that originates both within as well as beyond an individual's being, to initiate work-related behavior, and to determine its form, direction, intensity and duration (Trembley, Blanchard, Taylor, Pelletier, \& Villeneuve, 2009). Work motivation, can be further distinguished between intrinsic motivation (i.e., doing an activity for its own sake because one finds the activity inherently interesting and satisfying) and extrinsic motivation (i.e., doing an activity for an instrumental reason) (Ryan \& Deci, 2000) (Trembley, Blanchard, Taylor, Pelletier, \& Villeneuve, 2009). Although creativity research has relied on intrinsic motivation theory to explain creativity (Amabile, 1983) (Amabile T. , 1997) (Oldham \& Cummings, 1996) (George \& Zhou, 2007), it is rarely empirically assessed in applied settings (Dewett, 2007) (Shalley \& Giilson, 2004) (Tierney, Farmer, \& Graen, 1999), with few exceptions being (Shin \& Zhou, 2003) (Dewett, 2007) (Zhang \& Bartol, 2010). Extrinsic motivation leads to satisfaction of employee needs indirectly through monetary compensation and has been found to be significant predictor of performance of R\&D professionals (Manolopoulos, 2006).

One of the important topic about works motivation is what factor impact to work motivation. And the answer of this come from some research e.g. Rawung (2012) on her research finding that leadership has significant impact to work motivation in administration employee on university organization. Other researcher has similar finding as this research: in military organization (Wagimo \& Ancok, 2005); in university organization (Ariyani, 2011); in hospitality organization/industry (Prasastono, 2012); in public service organization (Widyanto \& Sutarno, 2011). The results of all research find that leadership has positively significant impact to work motivation.

Associated with the administrative aspect, effectiveness of working arrangement relating to administrative services system in university is largely determined by the high quality employee. Thus in terms of the administrative work services in university, the important of administration employees who has high productivity and high motivation must be number one priority (Rawung, 2012).

This research will add to both the motivation and the leadership literatures. Motivation is typically believed to be influenced by a combination of individual and contextual factors. Leadership can be a powerful 
contextual factor (Harrell, 2008). This study makes important contributions to leadership, work motivation, public or civic organization, higher education organization literatures. This study purpose examine link between leadership in state university to work motivation from administration employees.

\subsection{Leadership}

\section{FUNDAMENTAL THEORIES}

Former views about leadership illustrate that it is seen as a personal capability. However, base on opinion of Messick and Kramer (Messick \& Kramer, 2004) that the degree to which individuals' exhibits leadership depends on the characteristics and personal abilities, characteristics of the location and environment in which he finds himself. Furthermore, Messick and Kramer (Messick \& Kramer, 2004) explained that since human beings could become members of an organization in order to achieve certain personal objectives, the extent to which they are active members depends on how they are convinced that their membership will enable them to achieve their predetermined objectives. Therefore an individual will support an organization if he believes that through it, his personal objectives and goals could be met, if not the person's interest in the organization will decline.

Leithwood et al (Leithwood, Jantzi, \& Seinbach, 1999) contend that there is no agreed definition of the concept of leadership. Yukl (Yukl, 2002) adds that "the definition of leadership is arbitrary and very subjective. Some definitions are more useful than others, but there is no 'correct' definition." Cuban (Cuban, 1998) says that "there are more than 350 definitions of leadership but no clear and unequivocal understanding as to what distinguishes leaders from non-leaders".

\subsection{Work Motivation}

According to Watkiss (Watkiss, 2004), motivation is the way to drive person into doing something. Much of the driven are the thought of a potential reward, or a consequence of not doing something. Motivation is the forces the people do something: this is a result of the individual needs being satisfied (or met) so that individual has the inspiration to complete the task. Motivation refersto the initiation, direction, intensity and persistence of human behaviour. Based on the definition of Watkiss (Watkiss, 2004), it can be concluded that the motivation is the idea and initiative to encourage and drive the individual to do something or to performance better jobs.

At one time, employees were considered just another input into the production of goods and services. What perhaps changed this way of thinking about employees was research, referred to as the Hawthorne Studies, conducted by Elton Mayo from 1924 to 1932 (Dickson, 1973). This study found employees are not motivated solely by money and employee behavior is linked to their attitudes (Dickson, 1973). The Hawthorne Studies began the human relations approach to management, whereby the needs and motivation of employees become the primary focus of managers (Bedeian, 1993).

Understanding what motivated employees and how they were motivated was the focus of many researchers following the publication of the Hawthorne Study results (Terpstra, 1979). Five major approaches that have led to our understanding of motivation are Maslow's need-hierarchy theory, Herzberg's two- factor theory, Vroom's expectancy theory, Adams' equity theory, and Skinner's reinforcement theory.

According to Maslow, employees have five levels of needs (Maslow, 1943): physiological, safety, social, ego, and self- actualizing. Maslow argued that lower level needs had to be satisfied before the next higher level need would motivate employees. Herzberg's work categorized motivation into two factors: motivators and hygienes (Herzberg, Mausner, \& Snyderman, 1959). Motivator or intrinsic factors, such as achievement and recognition, produce job satisfaction. Hygiene or extrinsic factors, such as pay and job security, produce job dissatisfaction.

Vroom's theory is based on the belief that employee effort will lead to performance and performance will lead to rewards (Vroom, 1964). Rewards may be either positive or negative. The more positive the reward the more likely the employee will be highly motivated. Conversely, the more negative the reward the less likely the employee will be motivated.

Adams' theory states that employees strive for equity between themselves and other workers. Equity is achieved when the ratio of employee outcomes over inputs is equal to other employee outcomes over inputs (Adams, 1965).

Skinner's theory simply states those employees' behaviors that lead to positive outcomes will be repeated and behaviors that lead to negative outcomes will not be repeated (Skinner, 1953). Managers should positively reinforce employee behaviors that lead to positive outcomes. Managers should negatively reinforce employee behavior that leads to negative outcomes.

Many contemporary authors have also defined the concept of motivation. Motivation has been defined as: the psychological process that gives behavior purpose and direction (Kreitner, 1995); a predisposition to behave in a purposive manner to achieve specific, unmet needs (Buford, Bedeian, \& Lindner, 1995); an internal 
drive to satisfy an unsatisfied need (Higgnis, 1994); and the will to achieve (Bedeian, 1993). For this paper, motivation is operationally defined as the inner force that drives individuals to accomplish personal and organizational goals.

Motivation concerns energy, direction, persistence and equifinality - all aspects of activation and intention and has been a central and perennial issue in the field of psychology, for it is at the core of biological, cognitive, and social regulation (Ryan \& Deci, 2000). Given today's economy, a motivated workforce represents both a competitive advantage and a critical strategic asset in any work environment (Trembley, Blanchard, Taylor, Pelletier, \& Villeneuve, 2009). Organizational researchers see employee motivation as a fundamental building block in the development of effective theories.

\subsection{Relation Between Leadership and Motivation}

At the most basic level, leadership theories propose that leaders can have a powerful impact on individual, group, and organizational outcomes. Further, follower motivation is thought to be a primary mechanism through which leaders exert their influence. Thus it follows that if leaders wish to improve outcomes, they should enhance the motivation of their followers (Harrell, 2008).

Work motivation or motive of work is a reflection of personal attitudes and of attitudes towards group work and collaboration. Such as attitudes to every employee, motivation is also to some extent influenced by the factors of the leaders part, especially by the leaders wisdom (Rawung, 2012). Motivation to work is a major influenced by employee itself, make high achiever employees. In the results discusing leadership issues, especially in relation to work motivation, it can not be forgotten issue of leadership styles. There are four styles of leadership, e.g (Rawung, 2012): (i) where the exploitive authoritative style is very autocratic managers, has less trust to his subordinates, like exploiting subordinates, and paternalistic act, (ii) a good autocratic style (benevolentauthoritative), where the leaders or managers that are included in this system has a hidden belief, trust in subordinates, (iii) a consultative style manager, where managers give little confidence in subordinates usually the case when he needs information, ideas or opinions of subordinates, and still want to control the decisions he made, and (iv) participatory group style (participative group), where the manager has perfect confidence against subordinates. In each issue always count on to get ideas and opinions are from subordinates and subordinates intends to using the opinion constructively (Rawung, 2012). Based on research conducted several experts associated with work motivation, which essentially says that the model-oriented leadership to subordinates / employees will result in increased motivation to employee work. So it can be stated that the onset of the motive or motivation, a key condition for the achievement of organization. Based theoretical concepts above, it can be expected there is a positive leadership indirectly influence the work motivation (Rawung, 2012; Wagimo \& Ancok, 2005; Ariyani, 2011; Prasastono, 2012; Widyanto \& Sutarno, 2011).

\subsection{Hypotesis}

This presentation result then being consider as hypothesis, which is: Leadership were positively affected on work motivation of university administration employees.

\subsection{Research Model}

Based on the discussion about theory and hypothesis development that has been described previously, one research model can be seen in Figure below.

\begin{tabular}{|c|c|}
\hline $\begin{array}{c}\text { Leadership } \\
\text { (Lead) (X) }\end{array}$ & $\begin{array}{c}\text { Work Motivation } \\
\text { (WM) (Y) }\end{array}$ \\
\cline { 2 - 3 }
\end{tabular}

\subsection{Method}

\section{RESEARCH METHODS}

The researches was conducted in Manado State University Minahasa Regency North Sulawesi Province of Indonesia. According to data gained from Manado State University, amount of students are 15,768, 919 lectures, and academic administration staffs/employees 487 (UNIMA, 2013).

This explanatory research is a kind of research that try to explain relationship among variables through hypothesis test. This method enables research findings to be generalized across persons, settings, and time (Cooper \& Schindler, 2010). Unit of analysis in this research is administration staff of Manado State University.

Population is the entire group of people, events or things of interest that the researcher wishes to investigate (Sekaran \& Bougie, 2010). According to Sekaran and Bougie (2009) sample is a subset of a population that comprises some members selected from it. Research population is Manado State University academic administration staff, and sample of this research is using purposive sampling with criteria: bachelor 
degree, 5 years experience, total 184 populations and the sample are 55 respondents taken from $30 \%$ of population.

Data collection techniques use: (a) Questionaire, it become main instrument in this research that address to respondent; (b) Interview, is a technic to collect data with direct interview to respondent; (c) Documentation is a technic to learn exist company document that related with reasearch problem. The data being analyzed using regression analysis with $\mathrm{t}$ test and $\mathrm{F}$ test for the hypothesis test. Questionnaire apply on this research adopted from previous research used for research carry out by Rawung (2012). However, the questionnaire had undergo a slight some modification.

\subsection{Operational Definition}

Leadership in conceptual defined as the ability to influence others to understand and agree with what was done by others judgment/subordinates regarding emotional control, problem-solving skills, ability to communicate and how the ability to motivate others/subordinates (Rawung, 2012), and the operational definition is the assessment of the activities of employees influence others to understand and agree with what was done by other people's judgments/subordinate, the indicators e.g (Djaali \& Mulyono, 2008): (1) controlling emotions, (2) the ability to solve problems, (3) communication skills, (4) ability to motivate others / subordinates. Measuring this definition using 5 point Likert scale with 31 questions.

Work Motivation. conceptual definition of this term is the overall driving force within the individual that raises the work or activities, which describe the behavior towards work, intensity/work effort, persistance to achieve purpose, and the operational definition is every employee perception to all individual power to move inside the employee that measureing someone work motivation responding by administration staff in Manado State University organization (Rawung, 2012). Measuring this definition using 5 point Likert scale with 27 questions.

\subsection{Validity and Reliability Test}

The reliability of a measure is established by testing for both consistency and stability. Consistency indicates how well the items measuring a concept hang together as a set,Cronbach's alpha is a reliability coefficient that indicates how well the items in a set are positively correlated to one another (Sekaran and Bougie 2009). Since reliable scales are not necessarily valid, researchers also need to be concerned about validity. It assesses whether a scale measures what is supposed to be measured. Thus validity is a measure of accuracy in measurement (Hair, Tatham, \& Black, 2010).

\subsection{Research Object Description}

\section{Results}

Data collection for respondent profile from 55 respondents, all had bachelor degree, minimal experience in Manado State University 5 years or more. Majority of respondents are: female, age 31-40 years old, speciality in Economy Management, and Social Administration, year experiences 5 to 10 years.

\subsection{Instruments Validity and Reliability Testing}

After conducting face and content validity, the next step is convergent validity test to reinforce legality of research instrument. This convergent analysis being perform in order to obtain question item which can fulfill the requirement of good question item that accumulate into one variable (Hair et al., 2010). The validity and realibility of research instrument especially the questionnaire instrument tested and the result that the validity and reliability of this instrument for questionnaire capable for field research to the respondents.

\subsection{Hypotesis Testing}

Hypotesis testing in this research showed in the Hypotesis testing in Table 4.1. below.

Table 4.1. Hypothesis Testing

\begin{tabular}{|c|c|c|c|c|c|c|}
\hline Hypothesis & Relation & Coefficient & T-Stat & T-Table & $\alpha$ & Condition \\
\hline H1 & Lead $\rightarrow$ WM & 0.528 & 4.966 & 2,00 & 0,000 & $\begin{array}{c}\text { Accepted / } \\
\text { Significant }\end{array}$ \\
\hline
\end{tabular}

Source: processed primary data (2013)

In the hypothesis, can be said according to the hypotesis leadership had a significant effect on work motivation. It can been seen in $\alpha$ below 0,05 or below $5 \%$. That indicate that hypotesis one accepted or relationship between leadership and work motivation is significant in this research, especially leadership to work motivation in education administration employee higher education organization in Manado State University Tondano North Sulawesi, Indonesia. 


\section{Result Discussion}

The test results shows that the effect of leadership on work motivation, and the relationship significant and positive. It can be concluded that leadership has effecting to work motivation. Meaning, the leadership in Manado State University especially give motivation work to employee who works in that organization. This because of the most basic level, leadership propose that leaders can have a powerful impact on individual, group, and organizational outcomes. Further, follower motivation is thought to be a primary mechanism through which leaders exert their influence. Thus it follows that if leaders wish to improve outcomes, they should enhance the motivation of their followers.

These result are consistent with research conducted by some research and author in many different organizations (Rawung, 2012; Wagimo \& Ancok, 2005; Ariyani, 2011; Prasastono, 2012; Widyanto \& Sutarno, 2011). According to Rawung (2012) work motivation or motive of work is a reflection of personal attitudes and of attitudes towards group work and collaboration. Such as attitudes to every employee, motivation is also to some extent influenced by the factors of the leaders part, especially by the leaders wisdom. Motivation to work is a major influenced by employee itself, make high achiever employees. In the results discusing leadership issues, especially in relation to work motivation, it can not be forgotten issue of leadership styles: (i) where the exploitive authoritative style is very autocratic managers, has less trust to his subordinates, like exploiting subordinates, and paternalistic act, (ii) a good autocratic style (benevolentauthoritative), where the leaders or managers that are included in this system has a hidden belief, trust in subordinates, (iii) a consultative style manager, where managers give little confidence in subordinates usually the case when he needs information, ideas or opinions of subordinates, and still want to control the decisions he made, and (iv) participatory group style (participative group), where the manager has perfect confidence against subordinates. In each issue always count on to get ideas and opinions are from subordinates and subordinates intends to using the opinion constructively. Based on research conducted several experts associated with work motivation, which essentially says that the model-oriented leadership to subordinates / employees will result in increased motivation to employee work. So it can be stated that the onset of the motive or motivation, a key condition for the achievement of organization. Based theoretical concepts above, it can be expected there is a positive leadership indirectly influence the work motivation.

\section{Conclusion}

\section{CONCLUSION AND RECOMMENDATIONS}

Leadership affectcs employee work motivation. That is, leadership to work motivation in higher education employee especially in Manado State University Tondano, North Sulawesi Indonesia. Leadership is useful to motivate employee work in the organization especially in higher education or university organization. However different leaders has different style so to motivate work is very subjective to each leader. Some leaders lead by "iron hand" style but some leader lead by transformational style especially to motivate.

\section{Recommendations}

Based on finding, leadership could become important factor to motivate employee in organization especially in higher education organization. Because higher education is public service organization and usually related to students and lecturs or professors, so leaders in this organization must become agent of change and agent of services for this organization thus motivate the employee of this organizations must one of many priority to be taken of the leaders in this organization kind.

Manado State University especially from the top leaders like head of university, head of faculty, head of the departement program and head of bireaucrat must focus their attention to motivate employee especially administration employee to get higher employee performance also higher organizational performance especially higher education or university performance.

\section{References}

[1] Adams, J. S. (1965). Inequity in Social Exchange. In L. Berkowitz, Advances in Experimental Social Psychology. New York: Academic Press.

Amabile, T. M. (1983). The Social Psychology of Creativity. New York: Springer-Verlag.

[3] Amabile, T. (1997). Motivating Creativity in Organizations. California Management Review , 40 (1), 39-58.

[4] Ariyani, V. (2011). Impact of Transformational Leadership to Universities Educational Work Motivation in City of Madiun. Widya Warta , 35 (1).

[5] Bedeian, A. G. (1993). Management. New York: Dryden Press.

[6] Buford, J. A., Bedeian, A. G., \& Lindner, J. R. (1995). Management in Extension. Colombus Ohio: Ohio State University Extension.

[7] Cooper, D. R., \& Schindler, P. S. (2010). Business Research Methods. Singapore: McGraw Hill.

[8] Cortese, A. D. (2013, March-May). The Critical Role of Higher Education in Creating A Sustainable Future. Retrieved August 2013, from Scoop.org: http://scholar.googleusercontent.com/scholar?q=cache:ogU_f2ARnz0J:scholar.google.com/+university+role+to+creating+quality+e ducation\&hl=id\&as_sdt $=0,5$ 
[9] Cuban, L. (1998). The Managerial Imperative and The Practice of Leadership in Schools. Albany NY: State University of New York Press.

[10] Daresh, J. (1998). Professional Development for School Leadership: The Impact of US Educational Reform. International Journal of Educational Research, 29 (4), 323-333.

[11] Dewett, T. (2007). Linking Instrinsic Motivation, Risk Taking, And Employee Creativity in An R\&D Environment. $R \& D$ Management, 37, 197-208.

[12] Dickson, W. J. (1973). Hawthorne Experiments. In C. Heyel, Th Encyclopedia of Management (2nd ed., pp. 298-302). New York: Van Norstrand Reinhold.

[13] Djaali, H., \& Mulyono, P. (2008). Measurement in Education Sector. Jakarta: Gramedia Pustaka Utama.

[14] George, J. M., \& Zhou, J. (2007). Dual Tuning In A Supportive Context: Joint Contributions of Positive Mood, Negative Mood, and Supervisory Behaviors to Employee Creativity. Academy of Management Journal, 50, 605-622.

[15] Hair, J. F., Tatham, A. R., \& Black, W. C. (2010). Multivariate Data Analysis: Global Perspective. New Jersey: Prentice Hall.

[16] Harrell, M. M. (2008). The Relationships Between Leader Behavior, Follower Motivation, and Performance. Florida: Departement of Psychology College of Sciences University of Central Florida.

[17] Herzberg, F., Mausner, B., \& Snyderman, B. B. (1959). The Motivation To Work. New York: John Wiley \& Sons.

[18] Higgnis, J. M. (1994). The Management Challange. New York: MacMillan.

[19] Kreitner, R. (1995). Management. Boston: Houghton Mifflin Company.

[20] Leadership, N. C. (2001). First Corporate Plan: Launch Year 2001-2002. Nottingham: National College for School Leadership.

[21] Leithwood, K., Jantzi, D., \& Seinbach, R. (1999). Changing Leadership for Changing Times. Buckingham: Open University Press.

[22] Manolopoulos, D. (2006). What Motivates R\&D Professionals? Evidence From Decentralized Laboratories in Greece. International Journal of Human Resource Management , 17, 616-647.

[23] Maslow, A. H. (1943). A Theory of Human Motivation. Psychological Review , 370-396.

[24] Messick, D. M., \& Kramer, R. M. (2004). Psychology of Leadership: Some New Approached. Lawrence Erlbaum Associates, Incorporated.

[25] Oldham, G. R., \& Cummings, A. (1996). Employee Creativity: Personal and Context Factors at Work. Academy of Management Journal , 39, 607-634.

[26] Prasastono, N. (2012). The Impact of Leadership Style and Compensation To Employee Work Motivation in Semarang Muria Hotel. Jurnal Ilmiah Dinamika Kepariwisataan, 11 (2), 32-39.

[27] Rawung, F. H. (2012). The Effect of Leadership, Work Facilities, Work Ethic on The Work Motivation of Civil Administration in Manado State University. Jakarta: Postgraduate Jakarta State University.

[28] Ryan, R. M., \& Deci, E. L. (2000). Self Determination Theory and The Facilitation of Interinsic Motivation, Social Developmen, and Well Being. American Psychologist, 55, 68-78.

[29] Sekaran, U., \& Bougie, R. (2010). Research Methods for. Business: A Skill Building Approach. London: John Wiley \& Sons.

[30] Shalley, C. E., \& Giilson, L. L. (2004). What Leaders Need To Know: A Review of Social and Contextual Factors That Can Foster or Hinder Creativity. Leadership Quarterly, 15, 33-53.

[31] Shin, S., \& Zhou, J. (2003). Transformational Leadership, Conservation, and Creativity: Evidence from Korea. Academy of Management Journal , 46, 703-714.Skinner, B. F. (1953). Science and Human Behavior. New York: Free Press.

[32] Terpstra, D. E. (1979). Theories of Motivation: Borrowint The Best. Personnel Journal, 58.

[33] Tierney, P., Farmer, S. M., \& Graen, G. B. (1999). An Eximination of Leadership and Employee Creativity: The Relevance of Traits \& Relationship. Personnel Psychology, 52, 591-620.

[34] Trembley, M. A., Blanchard, C. M., Taylor, S., Pelletier, L. G., \& Villeneuve, M. (2009). Work Extrinsic And Intrinsic Motivation Scale: Its Value For Organizational Psychology Research. Canadian Journal of Behavioral Sciences , 41, $213-226$.

[35] UNIMA, M. S. (2013). Manado State University in Numbers. Minahasa: Manado State University.

[36] Vroom, V. H. (1964). Work and Motivation. New York: Wiley.

[37] Wagimo, \& Ancok, D. (2005). Transformational and Transactional Leadership Relationship with Subordinate in Military. Jurnal Psikologi, 32 (2), 112-127.

[38] Watkiss, S. (2004). Motivation: A Study of The Motivations for Members of a Volunteer Organisation. Rugby.

[39] Widyanto, B., \& Sutarno. (2011). The Impact of Transformational Leadership and Organizational Culture to Employee Performance Moderating By Work Motivation. Jurnal Manajemen Sumber Daya Manusia , 5 (1), 76-88.

[40] Yukl, G. A. (2002). Leadership In Organizations. Upper Saddle River, NJ: Prentice Hall.

[41] Zhang, X., \& Bartol, K. M. (2010). Linking Empowering Leadership and Employee Creativity: The Influence of Psychological Empowerment, Instrinsic Motivation, and Creativity Process Engagement. Academy of Management Journal , 53, $107-128$. 